\title{
El cartel como dispositivo estético-político
}

\section{Marcos Perearnau}

\author{
Universidad de Buenos Aires, Argentina
}

marcosperearan@gmail.com

Fecha de recepción: 23/03/2019. Fecha de aceptación: 19/05/2019.

\begin{abstract}
Resumen
Este artículo analiza el cartel como dispositivo estético-político a partir de su emergencia a fines del siglo XVIII, su introducción tardía en la esfera artística a través de las vanguardias del siglo XX (con especial atención a la obra de Bertolt Brecht), y el uso de los carteles en el arte contemporáneo en el marco del activismo artístico, más específicamente, en la escena teatral porteña. Todo cartel como dispositivo articula una relación singular entre lo decible y lo visible, enunciados y visibilidades, y halla su fundamentación más allá del ritual teatral en la política. Así, los carteles aparecen como un dispositivo privilegiado para capturar las imágenes y textos de una época.
\end{abstract}

Palabras clave carteles dispositivo estético Brecht activismo artístico arte contemporáneo

\section{The Poster as a Political Aesthetic Device}

\begin{abstract}
This article approaches the poster as a political aesthetic device, starting from its emergence at the end of the 18th century, continuing with its late introduction into the artistic sphere through the avant-gardes of the 2oth century (with special attention to the work of Bertolt Brecht), and finally focusing on the use of posters in contemporary art-more specifically, in the Buenos Aires theatre scene- in the context of artivism. Posters as a device articulate a unique relation between the utterable and the visible, between statements and visibilities, and they find their sense beyond the theatrical ritual in politics. Thus, posters appear as a privileged device for capturing the images and texts of a time.
\end{abstract}

Keywords

Posters Aesthetic Device Brecht Artivism Contemporary Art
Banderolas, estandartes, banners publicitarios, afiches, grafitis, pósters, vallas y monopostes en autopistas, remeras y pañuelos, pasacalles, cubiertas de libros y discos, anuncios en redes sociales y páginas web, son los herederos del axón griego o el alba romano. Nuestra percepción cotidiana está constantemente estimulada, seducida y agotada por la descarga de esos dispositivos, que se hallan en su mayoría 
apropiados por las ofertas de la industria cultural, las publicidades comerciales o la propaganda política. Máquinas que hacen ver y hablar, así refiere Deleuze al concepto foucaultiano de dispositivo, extendiendo una inmejorable definición de cartel. El cartel como dispositivo estético-político permite pensar la relación entre enunciados y visibilidades en permanente lidia y variación. Esta heterogeneidad radical entre lo dicho y lo visto es la que desplaza al cartel, en tanto dispositivo que se constituye al interior de un juego de relaciones de poder, que entra y sale del concepto de arte.

\section{Emergencia del cartel y el anuncio como voceros de la Modernidad: la Revolución llustrada}

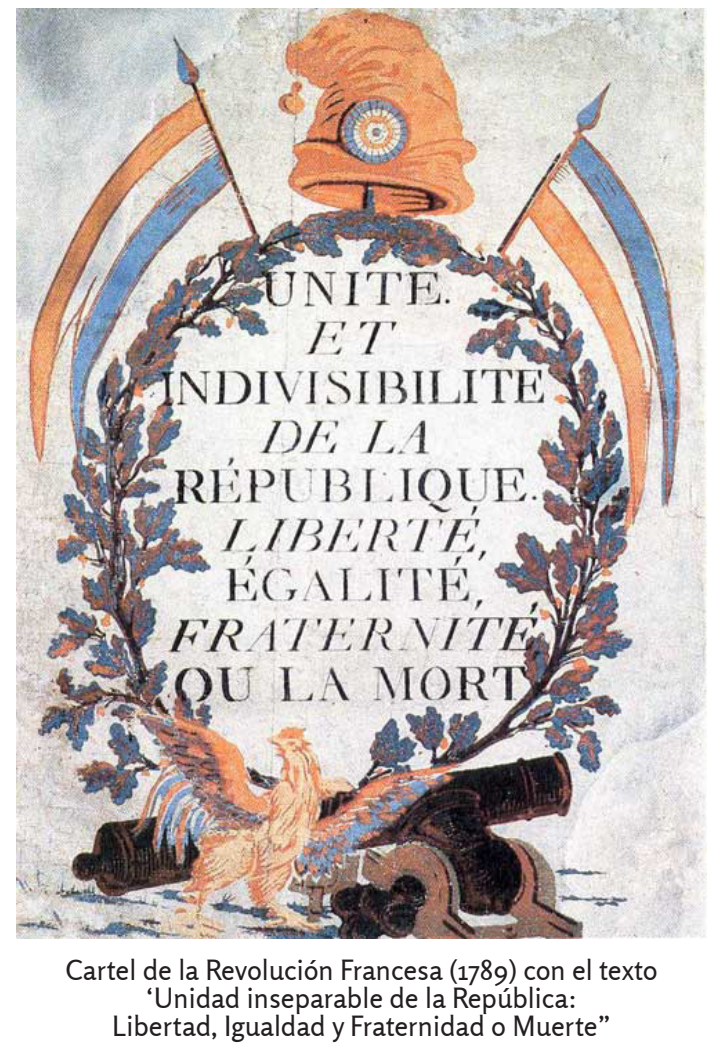

Es imposible precisar un origen de los carteles, puesto que no lo tienen. Lo que sí es posible determinar es que su aparición no sucede al interior de la esfera del arte autónomo, sino que es contemporánea a la constitución de esa misma esfera pública, es decir, "la esfera en la que personas privadas se reúnen en calidad de público" (Habermas, 1997: 58-64). Si bien hoy en día estamos dispuestos a admitir que un cartel exhibido en un museo -y cada vez más obras de arte contemporáneo utilizan los carteles como soporte- pertenece a la historia del arte, es recién a partir del siglo XX que los carteles fueron admitidos como objeto estético legítimo. Su origen profano retorna y se evidencia en la constante fuga y salida del espacio institucionalizado. El cartel mantiene esa doble pertenencia como objeto estético: es artístico y al mismo tiempo la negación del arte.

Comencemos entonces por la historia del cartel que aun no estaba contenida por el concepto de arte de la modernidad estética. Señaló Marx, en El 18 de Brumario, que en épocas de crisis revolucionaria se suele solicitar auxilio a los espíritus del pasado 
y "tomar prestados sus nombres, sus consignas de guerra, su ropaje, para, con este disfraz de vejez venerable y este lenguaje prestado, representar la nueva escena de la historia universal" (Marx, 2011: 17). Pero así como la revolución de 1789 se vistió con las prendas de la República Romana, y la revolución de 1848 fue una parodia de 1789 , también es cierto que ambas escenas revolucionarias, tanto la trágica como la cómica, utilizaron de forma extendida y privilegiada un dispositivo: los carteles. No se trata pues de una novedad en la historia de las revoluciones si consideramos que, a fines del año 1517, Lutero no solo se vistió de San Pablo, sino que la acción que dio inicio a la Reforma Protestante fue clavar un cartel con las famosas 95 Tesis en la puerta de la Iglesia de Todos los Santos y demás parroquias de Wittenberg. Y en esta misma línea, la crucifixión de Cristo, haya sido en forma de cruz comissa o inmissa (con el travesaño abajo), podría ser considerado el primer cartel de la era cristiana. Encima de la cabeza de Cristo podía leerse el titulus o letrero donde aparecía el cargo, según el Evangelio de Juan, decía «Jesús el Nazareno, el rey de

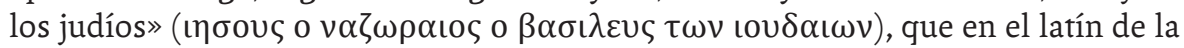
vulgata es «Iesus Nazarenus Rex Iudaeorum», esto es, INRI la sigla típica del arte cristiano de tradición latina.

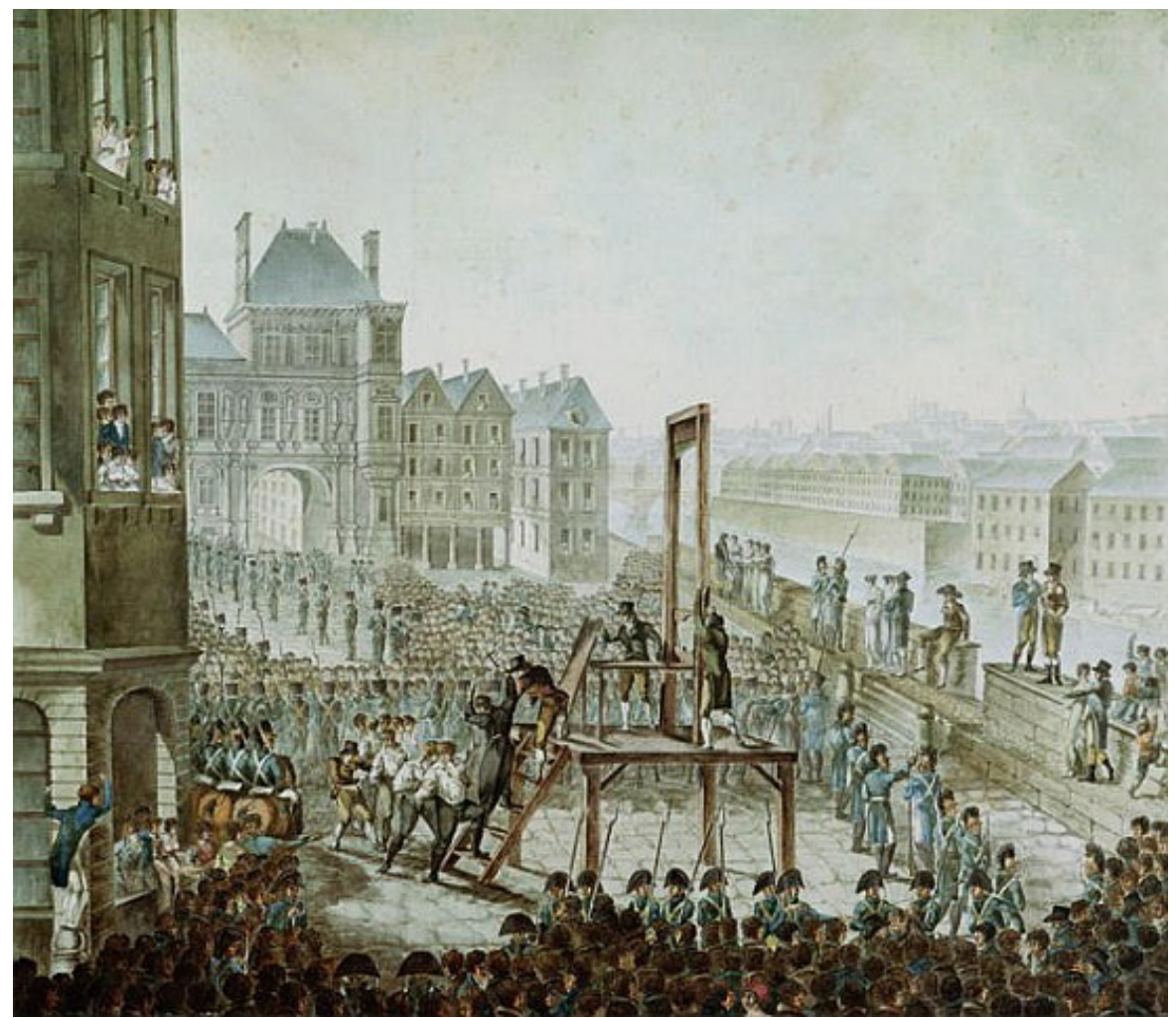

“La ejecución” de Georges Cadoudal (1804)

El cartel comparte con la guillotina el invento por antonomasia de la revolución burguesa, su principio fundamental: el corte. El primer cartel de la Modernidad, en este sentido, es la cabeza de Luis XVI colgando del brazo del verdugo en lo alto, en enero de 1793, en la plaza de la Concordia. Curiosamente, plazas como la de Concordia o la de Marte, donde se llevaron a cabo las ejecuciones, serán en poco tiempo el escenario de las Exposiciones Nacionales y Universales. Estas ferias y exposiciones de la industria son para Benjamin nada menos que el secreto esquema constructivo de los museos (Benjamin, 2013: 300), que alojarán cuadros como "La ejecución" de Georges Cadoudal de 1804. La separación entre la cabeza del rey y su cuerpo, tal como aparece en el cuadro de Cadoudal, abre una serie de rupturas 
que se extienden a todos los ámbitos, entre otros, a la desvinculación de las obras de arte de las colecciones privadas y paredes de los palacios. Y fundamenta, en última instancia, la creación del museo como aparato espacial que suspende la destinación cultual de las obras para que puedan ser contempladas por primera vez. El museo como dispositivo burgués está cortado con la misma tela que el cartel, y según Deotte, es "el aparato que inventa el arte en el sentido moderno de la estética" (Deotte, 2013: 286). Tiene la potencia de hacer aparecer un nuevo objeto: la obra de arte, un nuevo sujeto: el sujeto estético, y una nueva relación entre los dos: la contemplación desinteresada. Sería a partir del museo, según el filósofo francés entusiasta de los aparatos, que Kant habría podido formular su idea de un juicio estético desinteresado y contemplativo, porque son los aparatos modernos los que configuraron esa sensibilidad común y a través de los cuales la igualdad fue encontrada.

De modo que esa separación, que luego en Brecht será distanciamiento, exige ilustración e ilustraciones, salones y revistas, museos, manifestaciones y declaraciones, en definitiva, la formación del gusto. Un esfuerzo desmedido traccionado sobre todo por la educación cívica que ofrecen los revolucionarios franceses a través de sus abecedarios ilustrados y sus colecciones de cuadros históricos. La paradoja que surge es que la igualdad que está implícita en el juicio estético kantiano, universal y subjetivo, supone una revolución de la participación en lo sensible que no se cumple más allá de la estética. De allí la idea de una cultura afirmativa en Marcuse, como la gran coartada idealizante de la cultura burguesa en la cual la afirmación de un mundo valioso y obligatorio para todos solo se cumple en la interioridad del individuo. Terrible comprobación: en la producción capitalista, la igualdad abstracta de los individuos se realiza como desigualdad concreta. Más aún, el incumplimiento de la promesa de igualdad provoca su infinita demanda: "cada emancipación parcial produce situaciones que deben superarse nuevamente mediante la emancipación" (Koselleck, 2012:120).

Pocas décadas después de la Revolución francesa, señalaba Hegel, que el arte ya no procuraba la satisfacción que encontraron en él los pueblos en otros tiempos, porque la satisfacción de sus intereses "exige más bien reflexión" y estos se depositan en la esfera de la representación (Hegel, 2015: 63). El diagnóstico del fin del arte hegeliano implica haber advertido con enorme perspicacia en su tiempo el desplazamiento operado por el Romanticismo temprano: la satisfacción del ánimo no está en los objetos, sino en las reflexiones y pensamientos sobre el arte. Esa subjetividad romántica, que Schmitt definirá como la "agitación de una conversación animada", se expresa entre otras formas sensibles - esta es nuestra hipótesis- en los miles de carteles y afiches que emperifollaron los muros de la ciudad revuelta. Quien recoge estos carteles en dos grandes volúmenes bajo el título de Murailles révolucionaires es Alfred Delvau, publicados apenas cuatro años después de la revolución de 1848. En el prefacio, señala Delvau, que esas murallas revolucionarias son una obra "inmensa, gigantesca, única y en verdad sin precedentes, creemos, en la historia de los libros". Lo singular de esta obra, advierte, es su autor: se trata de una obra colectiva cuyo autor es "don Todo-elmundo". Esta subjetividad que aparece en los carteles es nada menos que aquella que caracteriza para Hegel a la subjetividad romántica, la oposición no resuelta y la contradicción no reconciliada. 


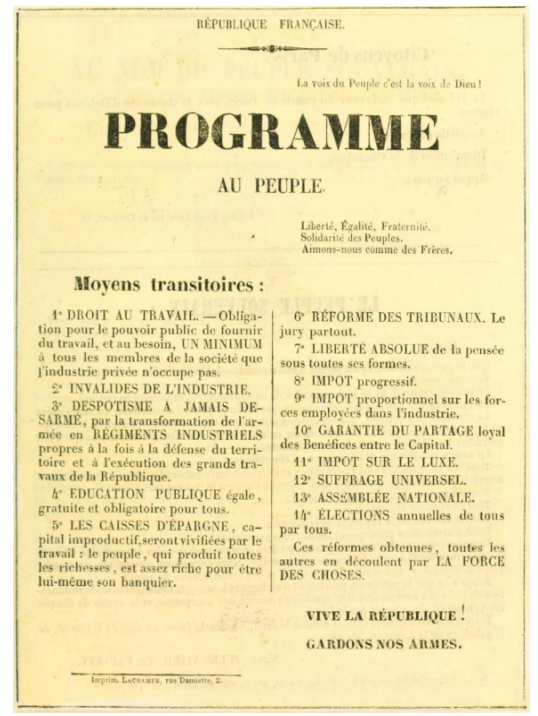

Murailles révolucionaires de Alfred Delvau (1852)

El libro de Delvau nos advierte que, durante la revolución de 1848, no solo las personas daban a conocer sus opiniones a través de carteles, sino que el propio Gobierno publicaba sus decretos y resoluciones a través de ellos. Tal es así que un librero se ve obligado a incluir una nota aclaratoria donde señala que el cartel no tiene relación con los sucesos políticos de su tiempo, sino con el simple anuncio de un libro. Esta anécdota es rescatada por Benjamin en "Exposiciones, Carteles, Grandville", quizás uno de los momentos en la Obra de los Pasajes, donde aparece con mayor nitidez la relación o acoplamiento entre las nuevas industrias recreativas y el capitalismo. Allí, la lectura aguda e inaugural de Benjamin de los carteles como objeto estético registra desde la aparición del vocablo anuncio, el cartel ambulante incorporado por el moderno hombre-anuncio, el contenido de los anuncios como el recuerdo de la Sal Bullrich en el metro, el éxito del estilo Jugenstil en plena calle, el volante con el que se anuncia una obra de teatro, hasta las obras maestras caligráficas en los letreros de los locales comerciales.

Cumplida la misión de terminar con las instituciones feudales y sus cabezas, la revolución francesa abandona el ropaje y frases romanas con las que instauró la sociedad burguesa moderna. Los carteles, en su vida post-revolucionaria del siglo XIX, se ubican a la altura o por encima de las cabezas de los transeúntes orientando el circuito de la mercancía en los locales comerciales de las galerías y pasajes. Carteles y vidrieras que se disputan la fantasía de los compradores y guían su sentido como un inconsciente vial en el estilo panorámico de la época que todo lo ensancha. Sin embargo, las hojas metálicas de los carteles, con sueños frescos de guillotina, amenazan con caer sobre la cabeza de los paseantes ocasionales.

\section{La introducción del cartel en la esfera del arte de las vanguardias a comienzos del siglo XX}

¿Por qué empezar una lectura de Brecht a partir del material de sus carteles? La obra de Brecht, al igual que cualquier propuesta de ruptura, está sujeta al proceso de naturalización que tiene lugar en la historia. $\mathrm{O}$, en términos del propio Brecht, todo acontecimiento puede ser reconducido a una dramaturgia aristotélica. Los carteles permitirían aplicarle a él mismo el efecto de distanciamiento que vuelve a disociarlo de lo naturalizado. Rompe con la continuidad de las narraciones, extrae de ellas diferencias, y al componer esas diferencias juntas, restituye el valor esencialmente crítico de toda historicidad. 


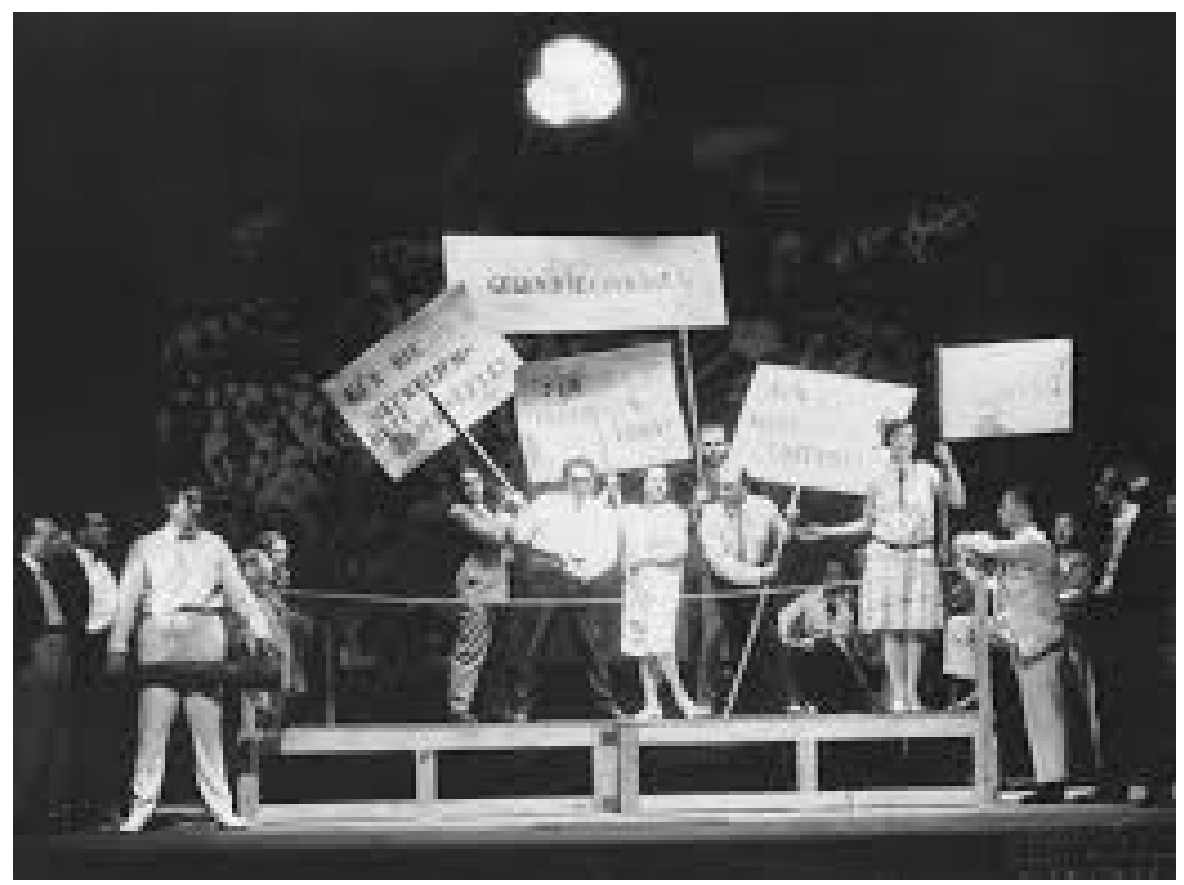

Das kleine Mahagonny (1927)

En ese sentido, el teatro brechtiano y su formulación no es pensable sino en el contexto de la escena dadaísta berlinesa crítica de la República de Weimar "el disfraz de la barbarie teutónica" y del expresionismo hegemónico de la posguerra. Quienes hasta entonces habían desandado caminos separados, a pesar de haber sido ambos hijos de la modernidad, el cartel y el museo, van a encontrarse a través de las vanguardias de comienzo de siglo XX. Pero no es sino a partir del cuestionamiento y negación de la autonomía del arte y el intento de superar sus límites, es decir un nuevo concepto de arte, que el cartel puede ser admitido dentro de la esfera artística.

Uno de los escenógrafos de Brecht -también de Piscator- era diseñador gráfico y quizás el más importante fotomontajista de la época: John Heartfield. No es casual entonces que coincidieran en una idea de escenario literalizado, esto es, concebir al escenario como una superficie de proyección, inscripción y exposición de los conflictos del presente; y que, en ese sentido, pudiera compartir y disputar el metraje de actualidad a los diarios, la radio y el cine. En las obras de teatro épico, y en esto Piscator era inigualable, podían cruzarse los títulos de las películas del cine mudo, las noticias y fotos de los diarios. Allí donde las formas del teatro épico se correspondían con las nuevas formas técnicas, la escena se volvía legible. El Benjamin de los años treinta, fascinado con el teatro épico, es el primero en señalar la literalización del teatro brechtiano, sobre todo, a propósito del ingreso de los carteles en escena. Hasta las proyecciones de Caspar Neher las considera carteles, y como tales, ideas materialistas que anuncian las escenas y no son mero decorado. Neher fue el más reconocido escenógrafo de Brecht, el compañero de escuela que dibujaba cuando Bertolt era el que hacía canciones; ambos nacidos en la ciudad de Augsburgo, la cuna de la Reforma. La literalización del teatro, sostiene Benjamin en el ensayo ¿Quées el teatro épico?, en su primera versión del año 1931, significa que lo figurado se mezcla con lo formulado, "dando así al teatro la posibilidad de establecer una conexión con otras instituciones para la vida del espíritu. Con otras instituciones y en último término con el libro mismo." (Benjamin, 1973: 36) Además de señalar el parentesco del teatro épico con prácticas chinas en el uso de las formulaciones, carteles, títulos, el objetivo principal de estos es despejar a la escena de su sensacionalismo temático. 


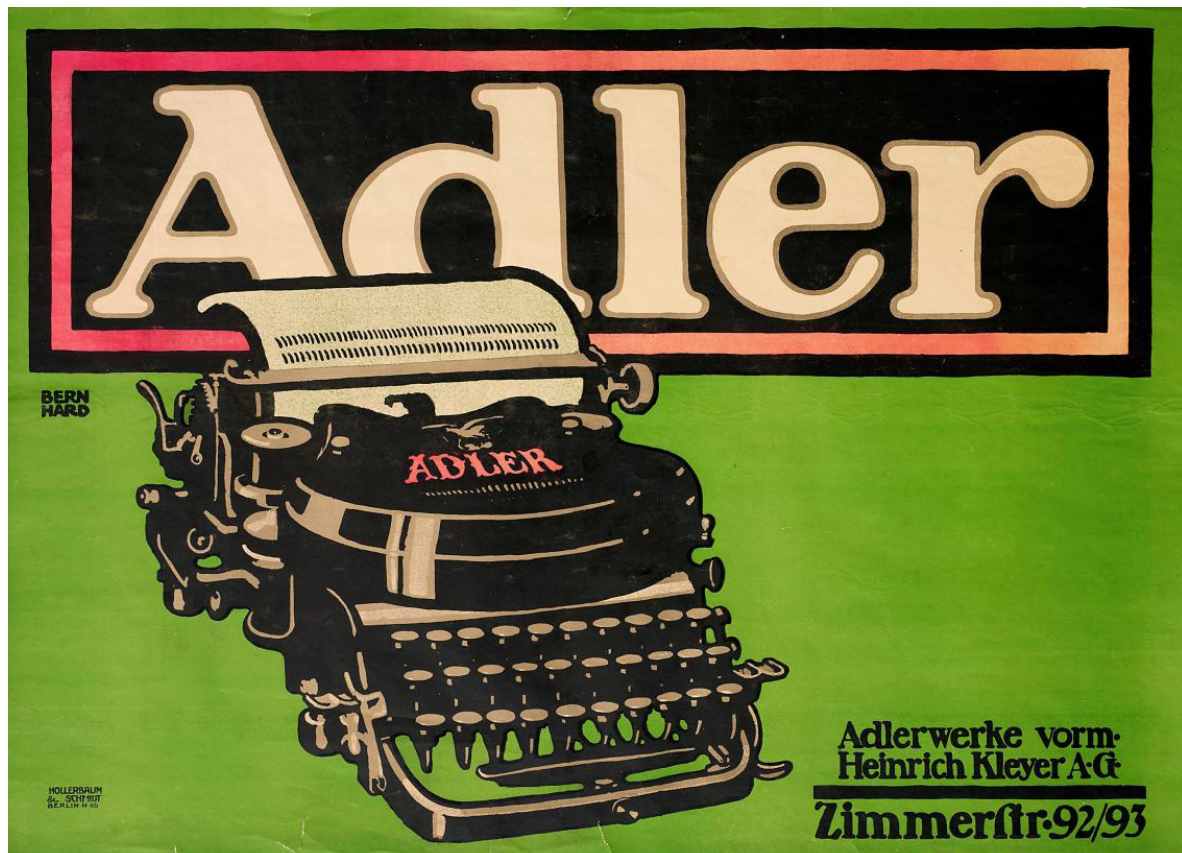

“Sachplakat” de Lucian Bernhard (1912)

El auge del afiche se dio con el Art Nouveau francés, pero en Alemania, luego del Jugenstil, quienes llamaron la atención a comienzos del siglo XX fueron los Sachplakat. Afiches que presentaban las cosas y se destacaban por el uso de la negrita -característico de Lucian Bernhard-, los colores puros y la simplificación de las formas. John Heartfield había fundado la revista Die Pleite junto al ilustrador George Grosz, con quien Brecht también trabajó. Die Pleite que publicaron entre 1919 al 1924, formaba parte de la escena dadaísta berlinesa crítica de la República de Weimar. Ambos obituarios del arte, más que artistas después del fin del arte, se consideraban ingenieros o maquinistas, idea que lucían vistiendo overalls. Llama la atención en esta fotografía de la primera gran muestra dadaísta en Berlín, la presencia abrumadora y proliferante de carteles. Hasta del muñeco de un oficial alemán con cara de chancho cuelga un cartel.

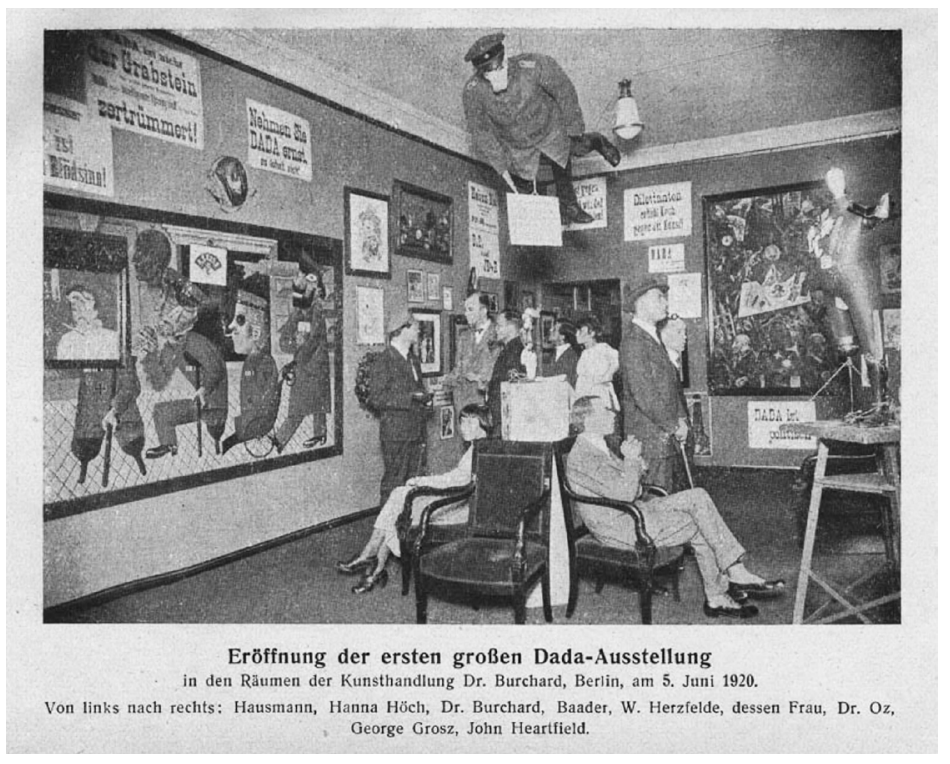

Inauguración de la primera exposición dada, Berlín, 5 de junio de 1920. 
A la derecha, aparecen Heartfield y Grosz, observando la escultura como si fueran meros espectadores. En otra fotografía, más difundida, se los ve a ambos sosteniendo el cartel que afirmaba la muerte del arte y auguraba una larga vida a la nueva máquina del arte. Cuenta Heartfield en una entrevista del año 67, que los dadaístas berlineses, ellos digamos, eran expertos aguafiestas de lecturas tradicionales. Solían interrumpir eventos de formas siempre originales e imprevistas. La más arriesgada de ellas fue la de Baader, en la que interrumpió la sesión de la Asamblea Nacional con panfletos que anunciaban la llegada del Dadá Supremo como juez máximo del Juicio Final. Aunque, como también señala, una vez que los poetas eran interrumpidos, el público advertía que se trataba de una nueva acción dadaísta. Es que el público de principios de siglo ya no aguardaba impertérrito al espectáculo, sino que deseaba ser escandalizado, ridiculizado y expuesto a estas situaciones disruptivas.

Es por ello que a la hora de intervenir y alcanzar a ese público general, los carteles se vuelven un dispositivo privilegiado de fuga hacia el exterior. El lugar en donde van a inscribir los dadaístas sus acciones es en la calle. Había que sacar la poesía a la calle, literalmente, como señala Roul Hausmann en su feroz artículo "El dada se subleva, se agita y muere en Berlín", porque "la palabra es una señal en medio de la calle." "A la palabra la hemos confundido y desfigurado en todos los sentidos, hemos hecho de su significado algo íntimo; pero yo, yo la he pegado en los muros sin muros, en poemas-carteles con letras de imprenta que gritaban al exterior la nueva desnudez" (Hausmann, 1970: 44).

En uno de sus escritos políticos, Brecht afirma que para su generación "la magna enseñanza objetiva práctica de una nueva manera de ver las cosas fue la guerra, y por cierto la guerra en su totalidad, o sea a través de un decurso de cuarenta años y el salto en la Revolución" (Brecht, 1972: 20). La Primera Guerra Mundial fue una guerra de trincheras -kilómetros y kilómetros de tierra tajeada-, que dejó un saldo de diez millones de muertos y el doble de soldados heridos con amputaciones y deformaciones, verdaderos collages vivientes. La derrota significó la caída del imperio alemán, la pérdida y separación de territorios, esto es, una Alemania que dejaba de ser aquel imperio capaz de la unidad de una Gesammelwerk, para vivir su desmantelamiento. En el Pequeño Organon, Brecht manifiesta su rechazo a la obra de arte total, porque entiende que en ella las disciplinas desaparecen y se pierden; en cambio, defiende una idea de colaboración de las artes en sus diferentes modalidades, consistiendo sus relaciones recíprocas pero distanciándose las unas de las otras. A diferencia de los dadaístas cuyo cuestionamiento de los límites de la autonomía del arte los llevaban a la calle y los carteles eran para ese propósito compañeros ideales, en el caso de Brecht, el cartel no sale sino que es introducido en la esfera artística. La incorporación de los carteles en escena implica el ingreso de un elemento profano al interior del teatro. El uso específico de los carteles en la obra de Brecht permite pensar ciertas estrategias de su funcionamiento como dispositivo, entre ellas el extrañamiento o corte, la emergencia del medio, el montaje y lo didáctico, además de abrir la posibilidad de considerar a los carteles como un pars pro toto de la obra de Brecht. 


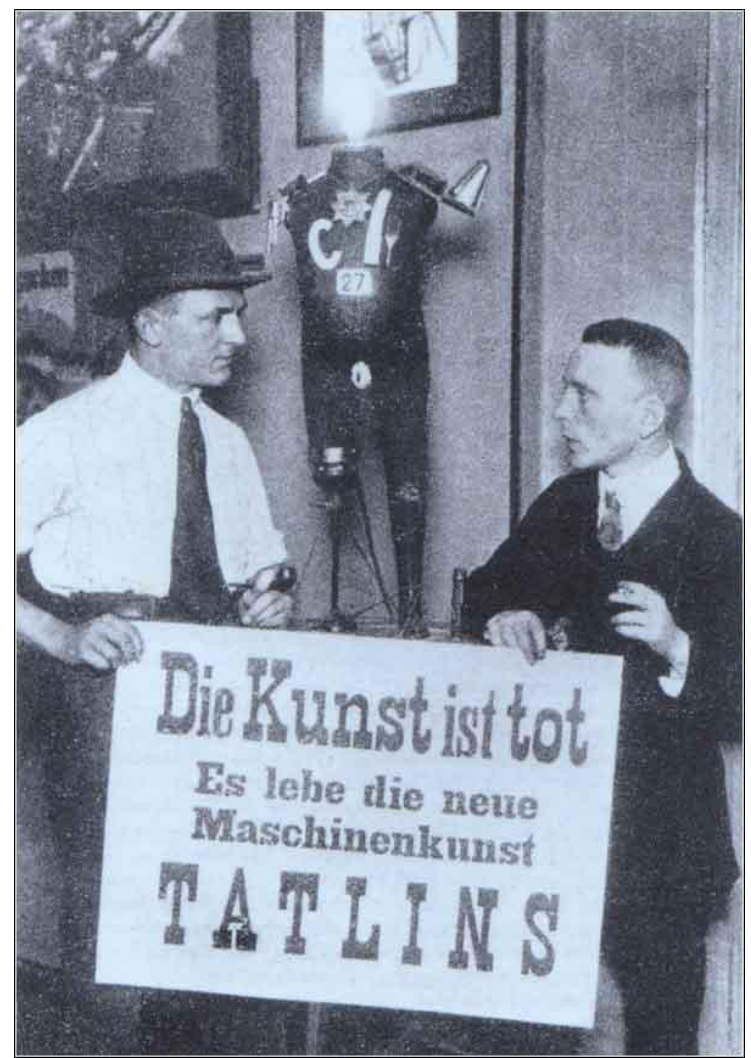

Grosz y Heartfield sosteniendo una pancarta donde se lee: "El arte está muerto. Viva el arte de la máquina de Tatlin"

\section{1) Extrañamiento como corte}

Verfremdung o extrañamiento parte de la crítica brechtiana a la dramaturgia aristotélica, como ha sido señalado, tiene su antecedente en la ostranenie del formalismo ruso. El teatro épico se define, en una primera instancia, como negación y en la confrontación con la dramática aristotélica. La crítica brechtiana a la Poética de Aristóteles está orientada menos al fin que le atribuye a la tragedia -la catarsis, es decir, la depuración del espectador despertando su miedo y compasión-, que al medio a través de la cual ésta se consigue: la identificación. El gran enemigo del teatro épico es la búsqueda de ese acto psíquico muy particular en el cual el espectador se solapa emotivamente con los personajes del drama y tiene como resultado la identificación. La imitación de las actitudes humanas por parte de los actores debe inducir al espectador a imitar al actor. De modo que la forma de captar la obra por parte del espectador es a través de un reflejo duplicado. El espectador se identifica con el actor y, a través de él, con el personaje de la obra. La dramática aristotélica no comprende solamente a aquel teatro de los griegos, sino al teatro contemporáneo de Brecht, y a todo aquel que tenga como principio la identificación. $Y$ es una constante que atraviesa toda la historia del teatro, puesto que "ese acto psíquico tan particular de la identificación se cumple de manera muy diversa en el transcurso de los siglos" (Brecht, 1970: 121).

La distancia o corte del $V$-Effekt evita la psicologización del conflicto y resolución dentro de la interioridad que supone la identificación. Al volverse el objeto extraño para la conciencia que intenta aprehenderlo, al no reconocerlo, se produce simultáneamente un proceso en el cual esa conciencia se encuentra con algo que es diferente 
a sí misma, que está afuera, y en cuyo intento de reconocerla impulsa un proceso de autoconciencia, historización y aprendizaje. Es por ello que la renuncia a la identificación en el teatro épico exige tanto del espectador como del actor una posición crítica y libre. El sabio espectador o vidente dentro de escena, que es para Benjamin el héroe no trágico característico del teatro épico, encarna esa dualidad en el actor que muestra y se muestra a sí mismo.

El cartel, junto con las canciones, juega un rol clave en la interrupción de la acción para producir el efecto de extrañamiento. "Cuanto con más frecuencia interrumpamos al que actúa, tanto mejor recibiremos su gesto" (Benjamin, 1973: 34). Lo que se logra con ello, a diferencia de la escena ilusionista del naturalismo, es mantener al público ininterrumpidamente consciente. El público no es abordado como individuo, sino como masa que participa y colabora, porque están en juego sus intereses. En esta dialectización del teatro, el actor se transforma también en espectador, al mismo tiempo que el espectador se transforma en actor. El espectador incorporado al acontecer teatral, "ya no es más un consumidor, sino que debe producir" y es, por así decir, teatralizado. En ese sentido, el público no es el mero número contabilizado por la industria cultural en consumidores, sino que en esta transformación cualitativa, deja de ser un individuo para devenir un ente colectivo. A ese espectador literalizado, según Brecht, es al que hay que formar, formar su disposición sensorial para vincularse con el material que ha sido declarado bien público. Solo entonces tiene sentido pensar que el teatro puede organizar la realidad.

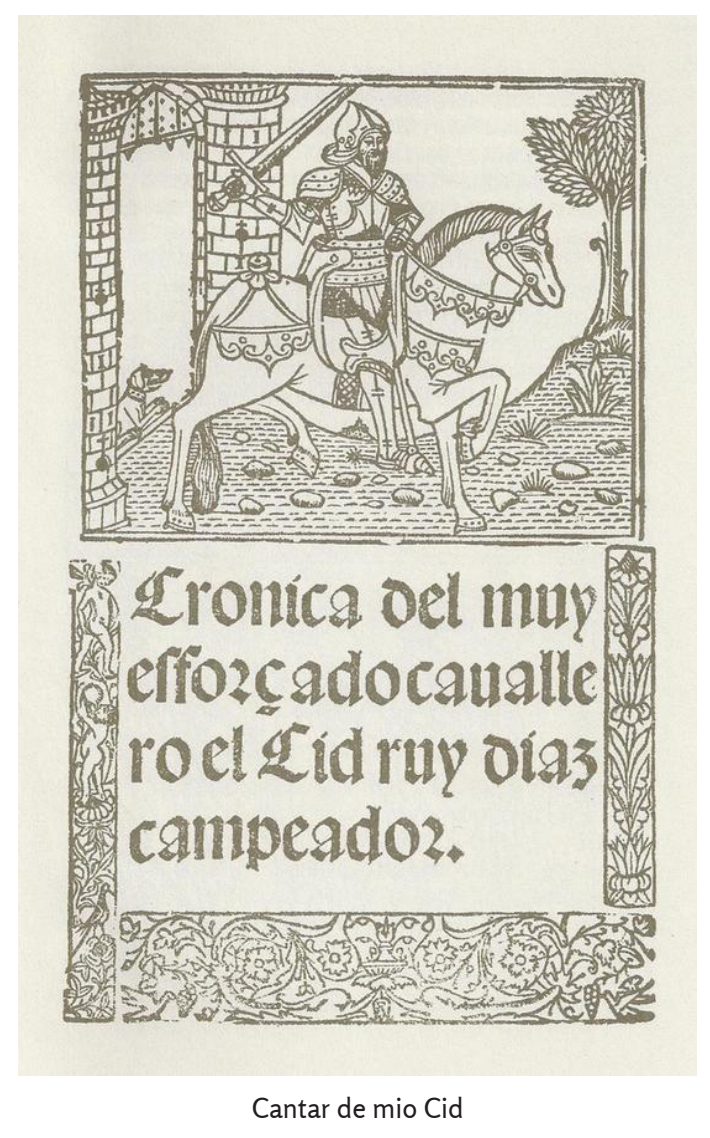

El desocultamiento de las obras que pertenecían a colecciones privadas y la realeza operada por los museos, además de desplazar el valor de culto por el valor de exhibición de las mismas (Benjamin, 2013: 63), construye al público en su condición de espectador y juez. Ese mismo público, ahora de masas en el siglo XX, se expresa 
ya no en el derecho a acceder a esas obras, sino a ser filmados. Es decir, así como "la emancipación, que saca diferentes procedimientos del arte fuera del seno ritual, aumentan para sus productos las oportunidades de ser exhibidos", el público que ya ha incorporado en su percepción el sistema de aparatos, tras haberse identificado con el museo y con la cámara, demanda ser exhibido, porque ya sabe comportarse frente a esos aparatos.

El cartel, en la época de Brecht, era un elemento extraño a la escena y, en tanto tal, tenía capacidad de interrumpirla. Implicaba al mismo tiempo la incorporación de una tecnología precapitalista de otro soporte, el literario, como los títulos de relatos épicos del Cantar del Mío Cid. La interrupción del proceso de la acción libera y descubre a las situaciones. Permite la tarea del historiador revolucionario, que según Benjamin, consistía en percibir la constelación instantánea saturada de tensiones y capturarla en una imagen verbal. Ese momento cognitivo, que atiende en el pensamiento no solo el movimiento de las ideas sino también su detención, es el que Benjamin llamaba "dialéctica detenida".

Con la suspensión de la identificación que propicia el teatro épico, la acción se pone al menos en tres nuevas relaciones, que a su vez están vinculadas. Una de ellas es la necesidad de reunir los fragmentos a través del montaje, la emergencia del medio o contexto en el cual se dan los acontecimientos y, por último, la relación de la acción con la reflexión y el conocimiento en una didáctica.

\section{2) El Montaje}

En "El arte y las artes", Adorno señala que el fenómeno originario del deshilachamiento del arte se encuentra en el principio de montaje "que se impuso antes de la Primera guerra Mundial con la explosión cubista”, luego con el dadaísmo y surrealismo. El montaje perturba el sentido de las obras de arte por una invasión de fragmentos salidos de la realidad empírica -que se sustrae a la legislación del sentido- y, al mismo tiempo, infringe un desmentido al sentido. Para Adorno, cuanto más deja un género entrar en él lo que no contiene en sí mismo, más participa de lo que le es extraño. En vez de imitar a las cosas, se vuelve virtualmente una cosa entre otras cosas, algo que no sabemos lo que es.

La fragmentación permite una nueva reunión o composición de los elementos. A menudo, Brecht citaba aquella frase de Alfred Doblin, que decía que "a diferencia de lo que ocurre en el drama, es posible cortar el relato en muchas piezas separadas, como se lo cortara con tijeras". Allí donde la narración dramática procede por continuidades y linealmente, el montaje épico revela las discontinuidades y saltos que operan dentro de todo acontecimiento histórico. La interrupción permite crear discontinuidades, desatar las articulaciones al límite de lo posible y hacer que las situaciones se critiquen dialécticamente. Es por ello que Benjamin compara el teatro épico con el avance a los golpes y choques de las imágenes cinematográficas.

El cartel tiene la particularidad de ser al mismo tiempo un fragmento, pero que se relaciona con los demás fragmentos de una forma particular. Es un fragmento que interrumpe la sucesión de fragmentos, es decir, tiene la facultad de interrumpir, pero, al mismo tiempo, tiene la facultad de referirse a los demás fragmentos otorgándoles algún tipo de unidad o relación entre ellos, como los carteles del cine mudo. No se muestra ni expone más que disponiendo: no las cosas mismas, sino sus diferencias, sus choques mutuos, sus confrontaciones, sus conflictos. Y toda exposición implica una autoexposición, como en el $A B C$ de la guerra, donde el desafío es cómo exponer 
la guerra, cuando uno mismo está directamente expuesto a ella. Un Brecht exiliado, fuera de lugar, pero con una posición tomada que puede advertirse en las distintas posiciones (disposición de las cosas, composición de las fuerzas, interposición de los campos y la posición del niño) de los documentos. Es como si, señala Didi-Huberman, "las trincheras abiertas en la Europa de la Gran Guerra hubieran suscitado, tanto en el terreno estético como en el de las ciencias humanas -Simmel, Freud, Warburg-, la decisión de mostrar por montaje, es decir, por dislocaciones y recomposiciones del todo." (Didi-Huberman, 2013: 77)

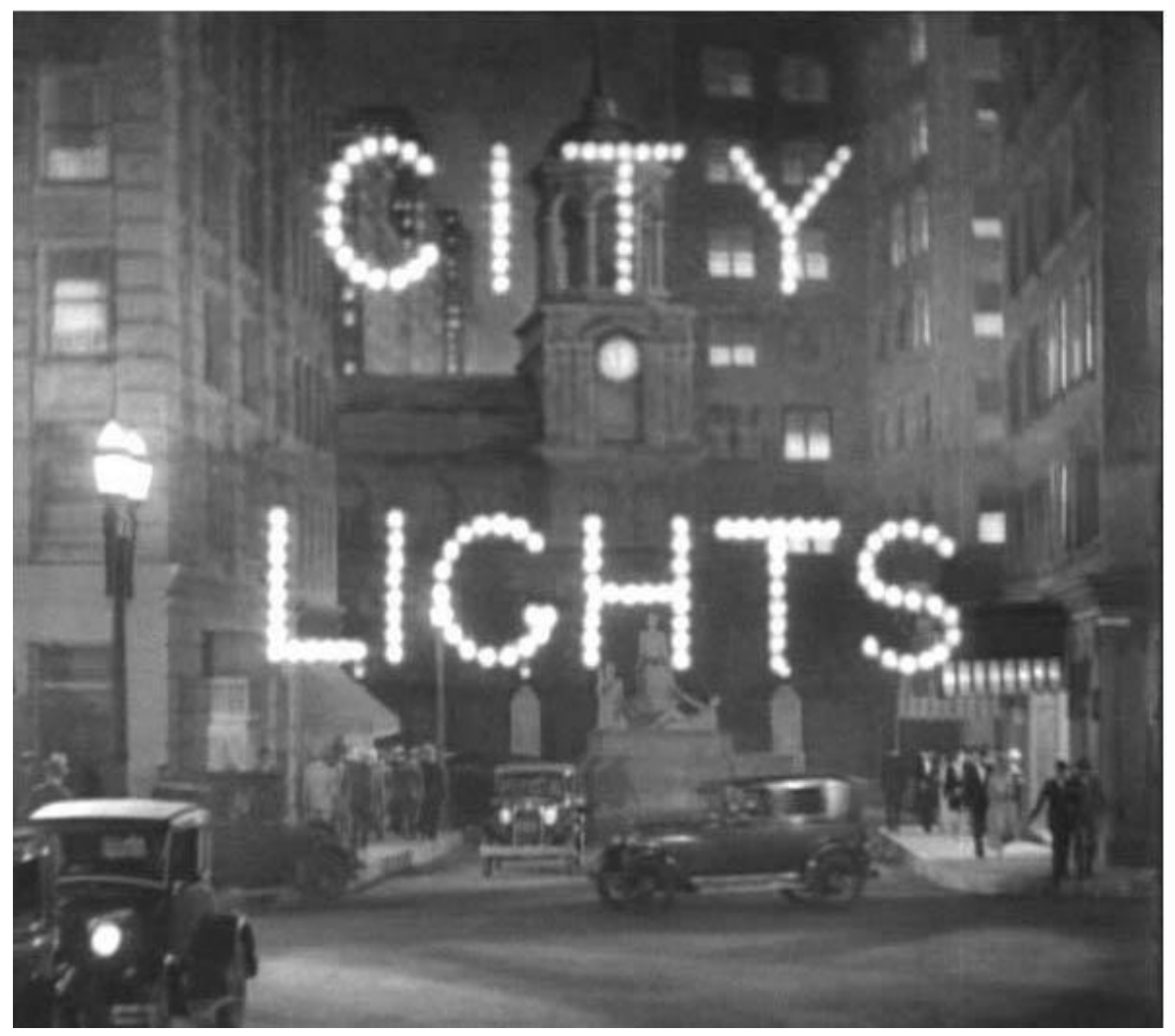

Títulos de Luces de la ciudad (City Lights), película de Chaplin estrenada en 1931.

Roto el continum de la historia, la reunión de los fragmentos tiene para Brecht una tarea que es una y al mismo tiempo doble. No se trata tanto de crear el material como organizar el material. Es por ello que Brecht abandona el antiguo concepto de obra vinculado a la fe en la personalidad y la experiencia del individuo, porque quienes sostuvieron la fe en la personalidad de la bella literatura, rechazaron la guerra y su enseñanza. No comprendieron que la guerra era un fenómeno social, lo vieron como un fenómeno de la interioridad del hombre. Es por ello que en la guerra vieron la negación de la persona, pero "la guerra era una realidad y la persona había desaparecido" (Brecht, 1972: 22). La creación ya no implicaba algo "orgánico", sino "organización". Y organizar el material es, al mismo tiempo, realizar la tarea formal de organizar el teatro revolucionario. Esa es la doble tarea que se cumple en la idea de montaje como organización. Es por ello que no se trata de montar cualquier imagen, sino de generar una imagen practicable del mundo, imágenes que movilicen y presenten al todo como modificable. En ese sentido, los carteles son portadores de consignas para la acción colectiva que deben orientar el sentido de la movilización. 


\title{
3) Emergencia del medio
}

En "Dramática no aristotélica", Brecht señala que para la comprensión de los sucesos se hizo necesario destacar el medio en el que habitaban los hombres. El medio, ya no como en la dramaturgia anterior, esto es, surgiendo de la reacción del héroe a sus estímulos como ante una tormenta, sino que el medio debía aparecer como factor autónomo. En el medio teatral, afirma Brecht:

El decorado de fondo tomaba ahora posición frente a los sucesos que acontecían en la escena, recordando, por medio de grandes cartelones, otros hechos desarrollados simultáneamente en otros lugares; contradiciendo o confirmando las declaraciones de algunos personajes proyectados; aportando a discusiones abstractas cifras concretas, fácilmente captables; ilustrando, mediante cifras y citas, episodios plásticos de sentido poco claro (Brecht, 1970 : 127).

En este proceso de distanciamiento más que de alejarse, de lo que se trata es de incluir lo que permanecía fuera del teatro; así, el petróleo, la inflación, la guerra, las luchas sociales, se volvieron por primera vez temas teatrales. El teatro épico pretende estar, como los carteles, en el medio de la discusión. Los carteles suponen una toma de posición por quien los sostiene. Y logran escribir dentro del teatro los textos del contexto. En ese sentido, los textos de los carteles exigen detectar en el contexto la carga social, emocional y emancipadora de ciertos enunciados. Y, al mismo tiempo, solicitan una enorme concentración de sentidos en la palabra, cuyo correlato y referencia es la concentración de las masas en las movilizaciones sociales.

\section{4) Lo didáctico}

\author{
¡Lo que no sabes por ti, \\ No lo sabes! \\ ¡Estás llamando a ser un dirigente!
}

Es conocida la anécdota de la expulsión de la escuela de Brecht con motivo de su revisión de un poema de Horacio. En plena campaña de alistamiento para la Primera Guerra Mundial, Brecht modificó el verso Dulce et decorum est pro patria mori (Dulce y honorable es morir por la patria), para señalar que se trataba de propaganda dirigida a los estudiantes. Didi-Huberman señala a propósito del Kriegsfibel, el ABC de la guerra, que para Brecht la poesía es parte de la pedagogía; no solo porque su material debe formar parte de un nosotros histórico y político, sino "porque su misma expresión no tenía sentido más que abriéndose al mundo social, realizándose en un proceso de transmisión." (Didi-Huberman, 2013: 178) El abecedario es paradójico: es una obra en que la lectura es pensada no en su voluntad de comprender el mensaje contenido en el texto, sino en su gesto fundamental de aprehensión de las letras. En las artes de la memoria o las obras de la pedagogía antigua, las letras se ponen a hacer gestos. Se organizan sobre una estructura de visibilidad de los cuerpos o los objetos y, recíprocamente, los cuerpos y objetos buscan desplegarse en colocaciones de legibilidad. El mejor ejemplo de ello es el alfabeto visual Ars reminiscendi de Giovan Battista Della Porta del año 1602. 


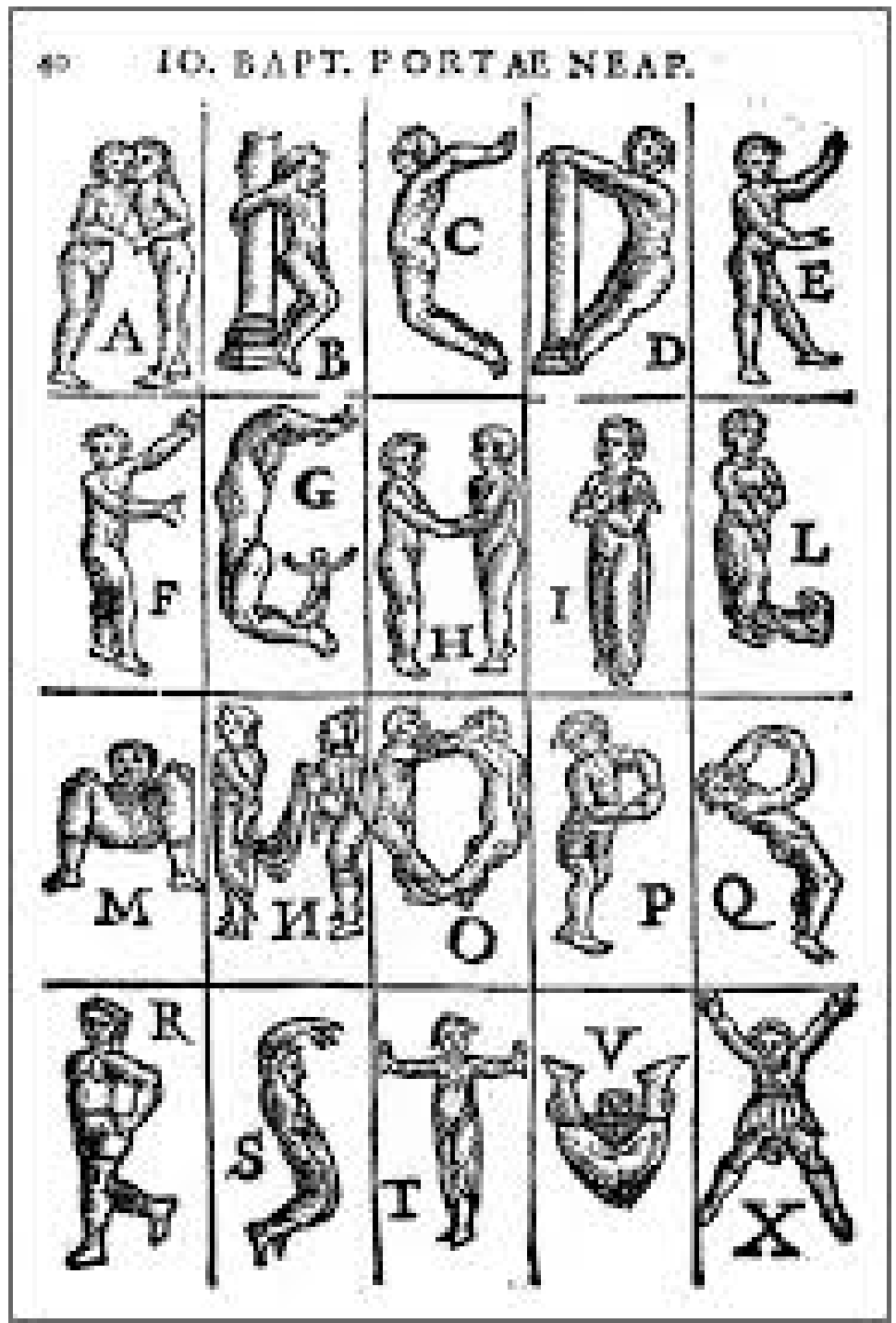

Ars reminiscendi de Giovan Battista Della Porta (1602)

El proceso de aprender el orden de las letras o la lectio -el lenguaje organizado en mensaje o discurso del saber-, pone en marcha también un proceso de jugar-la delectatio- con esos órdenes desmontando todas las partículas de la lengua organizada. El mundo es presentado menos en sus principios que en sus elementos simples y divisibles, que son fragmentos que podrán ser reorganizados según la fábula. Frederic Jameson señala que, al momento de deconstrucción lúdica en Brecht, le sigue siempre un momento de reconstrucción histórica, colectiva y revolucionaria. Este momento deconstructivo del conocimiento es placentero, porque el sujeto se deja modificar por el entorno y, a su vez, puede modificarlo. No es placentero cuando se considera al sujeto como algo mecánico que no ofrece resistencias. 


\section{El cartel fuera de escena: el espacio de aparición}

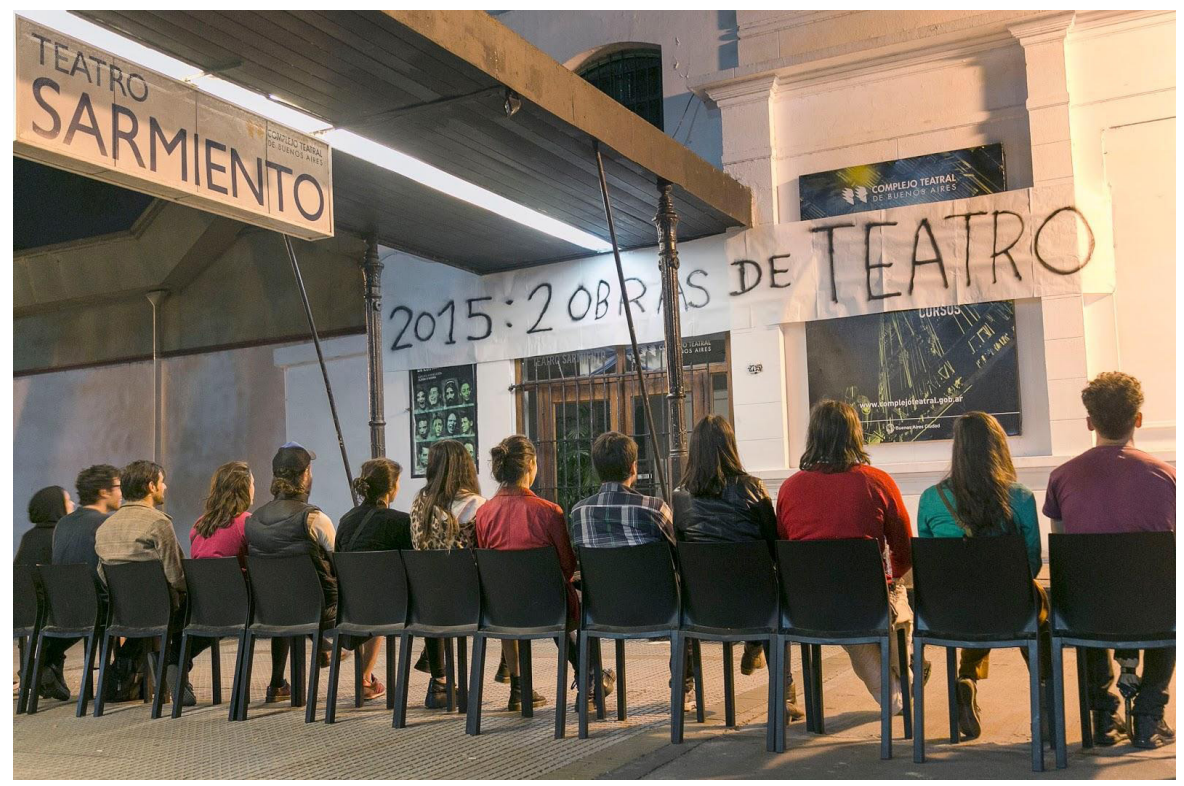

Foto Sebastián Arpesella.

Quienes se muestran de espaldas a cámara son actrices, bailarines, actores, en suma, artistas escénicos. Están sentados frente a las puertas cerradas del Teatro Sarmiento, un teatro municipal que pertenece al Complejo Teatral de Buenos Aires -que incluye siete de los teatros públicos más importantes del país-, en cuya entrada hay un cartel que anuncia que durante el año 2015 se han realizado apenas dos obras. Los artistas escénicos hacen de público. Llevan sillas frente a las puertas del teatro, cuelgan un cartel y actúan de espectadores. Este volverse público de los artistas pone en escena y vuelve pública una política cultural que no los incluye, que los deja fuera de sus salas y que persigue con clausuras a los espacios escénicos alternativos y autogestionados por los artistas. Más que poner en escena hay un pasaje a la puesta en común de un conflicto y el devenir del actor en un factor social en el cuerpo colectivo. Así como Brecht introducía el cartel al interior de la escena, en este caso, los artistas operan un primer desplazamiento del cartel fuera de la sala, en principio, a las puertas del teatro.

El colectivo Escena Política se presenta como un grupo de artistas vinculados a las artes escénicas de la Ciudad de Buenos Aires, articulados a través de dos espacios de activismo cultural, FDA (Foro Danza en Acción) y TIM (Teatro Independiente Monotributista). Durante 2015, se reúnen para realizar una serie de acciones que intentaban visibilizar críticamente a las políticas culturales y dinámicas de producción. La paradoja de esta acción es que es una inacción, los artistas sin trabajo y desalojados de las salas son desplazados al lugar del público y, brechtianamente, muestran a la vez la situación y a sí mismos. Ahora bien, es desde la asunción de ese lugar de público que los artistas juzgan al teatro en los términos de la política cultural que los deja fuera de sus salas: miden al teatro en números. Porque el público, al igual que la democracia, se mide en números.

En el marco de la vida administrada y hegemonía de la lengua universal de la gestión, el principio que rige es que para que algo aparezca y se realice debe ser previamente algo calculable. Debe convertirse en un presupuesto, una cifra. Se empieza el proyecto, si contamos con el presupuesto. Este es el dispositivo de la actual forma cultural, el presupuesto, que permite desde adentro la disolución de la cultura alternativa y las 
artes en industrias creativas, y con ello, para Adorno, la internalización de la totalidad. El cine nace como industria; las artes de la escritura, el teatro, la danza, no. Con la introducción de la gestión en la producción artística, ya no son los productores quienes ajustan las producciones artísticas a las planillas de rentabilidad, sino que son los propios artistas los que deben demostrar previamente la calculabilidad y previsibilidad de su proyecto para que sea financiado. De este modo se colabora en la cuantificación de la cultura, que para legitimarse debe exhibir cifras.

El presupuesto es una máquina de guerra que se acopla perfectamente al flujo de la cultura independiente. Una de sus potencias, que el macrismo puso en acción desde el comienzo como política cultural, es como máquina registro. En sus trazados de mapas de espacios culturales, encuestas, encuentros con artistas y gestores culturales de espacios independientes para extraerles información, más que realizar políticas culturales a medida de las demandas del medio, fueron disciplinando y controlando la escena. A la cultura se la vence haciéndole rendir subsidios y que se rinda ante éstos. La cultura alternativa se vuelve, a través de la mediación de la gestión, en una categoría más dentro del mercado cultural. Es de este modo que la política cultural oficial logró imponer este nuevo principio de calculabilidad al que respondieron siempre las industrias culturales, con la colaboración inadvertida de los artistas.

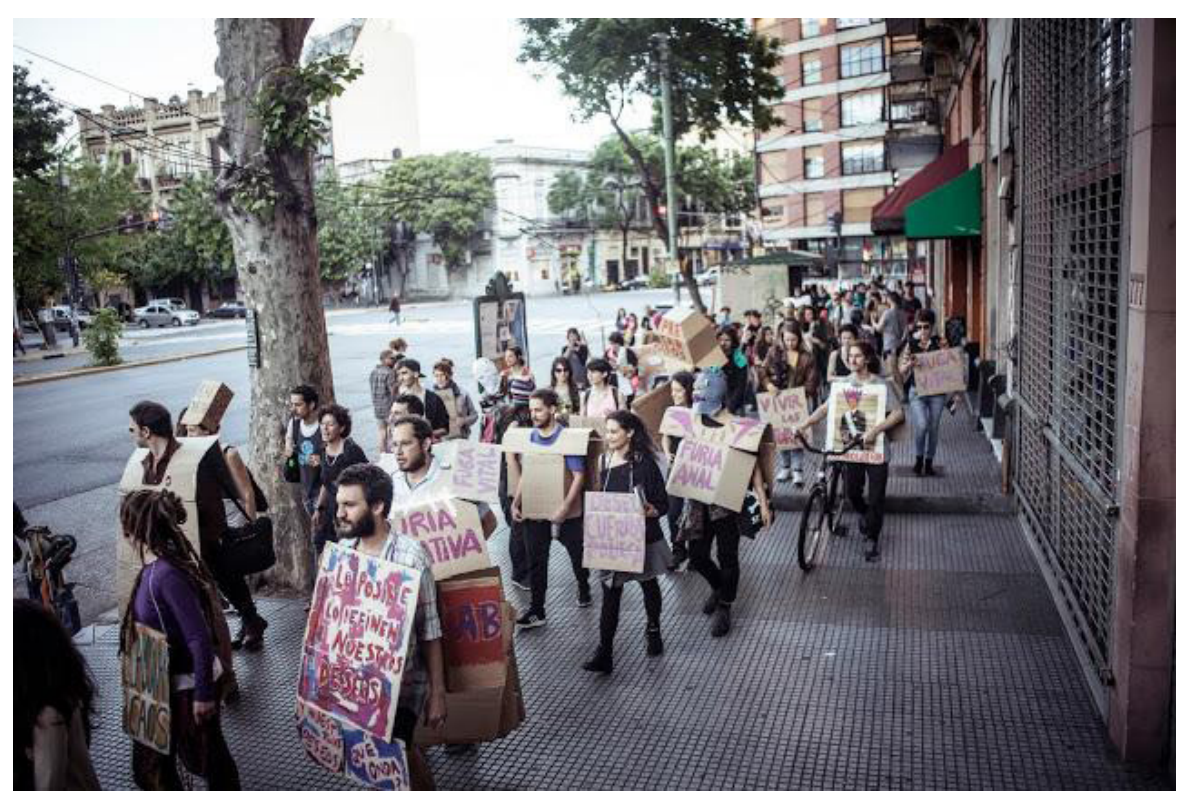

Foto Lina Etchesuri para Lavaca

Luego de este primer momento de acciones orientadas a la visibilización y señalización, los integrantes del grupo Escena Política se preguntaron si "tenía sentido seguir siendo los auditores sociales del Estado, aquellos que observan y señalan las faltas de una política cultural que nos resultaba completamente ajena, con la que no encontrábamos aperturas para habilitar un diálogo". O si, en todo caso, en un contexto así no convenía utilizar el tiempo en la imaginación de nuevas formas de vida y de producción cultural. Todos sus textos están disponibles en su sitio web http:// www.escenapolitica.info.

El objetivo sería entonces "contaminar la política con aquello que a priori creemos que no es la política, es decir nuestras prácticas artísticas". La respuesta y elaboración de este interrogante fue el armado, a lo largo de un año entero, de un Congreso Transversal, que se realizó en octubre de 2016. El objetivo del mismo era articular 
y cruzar "lo que no entra en la cuenta de la política tradicional, la academia y las instituciones del arte". Generar un espacio de pensamiento y acción que posibilitara al grupo "armar su propia agenda o temporalidad política, sin correr detrás de los problemas de la coyuntura, generando así modos propios de resistencia inventiva desde nuestra cotidianeidad amenazada".

Así como Brecht intentaba incorporar el afuera al adentro del teatro, es decir, ampliar el texto teatral al contexto general; la propuesta de estas acciones pareciera que tienen el objetivo de salir del texto para abrirse al contexto. Salirse también de los textos curatoriales e institucionales que dirigen la imaginación de los artistas, que se adecuan a ellas para poder recibir los subsidios y desarrollar, involuntariamente, realidades y deseos ajenos. El objetivo, en cambio, es darse los propios contenidos. No habría más público entonces que la comunidad ampliada de artistas e investigadores. De modo que la acción no está orientada hacia un espectador que habría que formar, como en Brecht, sino que su apuesta pedagógica promueve la forma estética del congreso para la autoformación de los artistas, en el doble sentido de darse y formarse en saberes transdisciplinarios (por fuera de los saberes escénicos) y constituirse como grupo o colectivo. No hay ningún yo que sea anterior a la concurrencia o que preserve una integridad anterior al campo cultural conflictivo.

Lo trans pareciera ser el universal de esta época, pues se muestra como el único capaz de englobar una totalidad, en un contexto general de fobia a cualquier tipo de totalización. No subsume a sus particulares de una forma vertical o en cruz, sino transversalmente, es decir, es una línea que cruza al menos otras dos líneas. Un ejemplo de transversal es el signo de diferente ( $\neq$ ), que implica el signo de igualdad dado por dos líneas rectas, atravesadas por una diagonal. La diagonal viene a dividir, cortar y barrar esa igualdad o identidad, que resulta en una totalidad dividida. Así, la hipótesis del sistema binario de géneros sostenida en la idea de una relación mimética entre sexo y género, vela la discontinuidad radical de la distinción sexo/género, en tanto el género no es sino los significados culturales que acepta el cuerpo sexuado (Butler, 2018: 54) Podemos señalar, entonces, un desplazamiento del reclamo por la igualdad en los activismos de fines del siglo XVIII, a la demanda por el reconocimiento de la diferencia y el derecho a lo diferente, lo queer.

El uso irónico de la forma congreso, tanto en su dimensión parlamentaria como académica, admite una pedagogía de la desobediencia (no de Ilustración) basada ya no en la igualdad, sino en la diferencia. Cada día el Congreso tuvo un eje temático sobre el cual giraron las actividades, pero vamos a detenernos en el cuarto y último día, donde se intentó "ensayar y crear nuevas formas colectivas de componer y habitar el espacio público". En el Centro Cultural Torcuato Tasso, se constituyó el "Comité Cósmico de Crisis", donde por más de tres horas compartieron el espacio cuatro talleres funcionando en simultáneo. El artista Osías Yanov, coordinó el Taller "Corte de Ruta y Pasarela", para inventar técnicas personales de transformismo deambulante y desplegarse en el tiempo-espacio de la caminata-caravana. La artista visual y activista, Mariela Scafati, coordinó el Taller de "Cartelismo", memoria activa de lo compartido durante las jornadas previas del Congreso, traducido en consignas de cartel. La confección de los carteles, con sus frases, sus formas, sus colores, sus materiales, fue también el catalizador de un pensar haciendo en torno al desplazamiento de nuestras palabras, voces y cuerpos en el espacio público. "Canciones del Presente para la marcha del futuro", taller coordinado por Luci Cavallero y Guillermina Etkin, hizo de las resonancias del trabajo desarrollado en el congreso, letras y melodías de canciones para la manifestación. El Colectivo Foro Danza en Acción articuló un taller en torno a la generación de prácticas de transferencia y contagio de movimiento, pensando el cuerpo en manifestación. 
En su artículo "ManiFIESTA", la investigadora María Daniela Camezzana propone la conjunción entre la manifestación y la fiesta en el término "manifiestación" para pensar los sentidos que subyacen a la idea de poner el cuerpo y qué potencia reconocen en la acción performática como participación política. La manifestación de la contradicción en los propios cuerpos, de sus desórdenes, se ejerce a través de la fiesta o manifiestación pública. Así como aparecía en Brecht el elemento de lo "divertido" en la pedagogía, la manifestación es una forma cultural a través de la cual se realiza una formación y elaboración performática del y en el conflicto. Los carteles como dispositivos, interrumpen el vínculo naturalizado entre la ley como instrumento y el cuerpo como superficie de inscripción, y permiten despejar el espacio público en el "entre" de los cuerpos. Es en ese sentido que Judith Butler presenta en "Cuerpos en alianza y la política de la calle" la idea de un espacio de aparición:

Para que esta puesta en cuestión funcione, tiene que haber una lucha por la hegemonía sobre lo que vengo llamando el espacio de aparición. Esa lucha interviene en la organización espacial del poder, que incluye la asignación y la restricción de ubicaciones espaciales en las que, y a través de las que, una población puede aparecer, lo que significa que hay una restricción espacial sobre cuándo y cómo la "voluntad popular" puede aparecer. (...) Al arrebatar ese poder, se crea un nuevo espacio, un nuevo "entre" de los cuerpos, por así decirlo, que reclama el espacio existente a través de la acción de una nueva alianza (Butler, 2017: 81).

Ese espacio de aparición se ejerce performáticamente, donde no solo crea un "entre" los cuerpos, sino también un "entre" el propio cuerpo. La división del propio cuerpo se articula en una idea de montaje de sí, cuyo origen está en el travestismo, donde la transformación se ejerce en el transformismo. El montaje del estar montadas no tendría tanto que ver con el trabajo brechtiano sobre los documentos de los diarios de la época, sino con el propio cuerpo como espacio de elaboración y exposición del conflicto, allí donde lo personal es político. El cuerpo deja de ser un mero instrumento o medio que se relaciona externamente con un conjunto de significados culturales, para, a través de un "laboratorio de lo que nos gobierna", reconocer las violentas operaciones de binarismos (que son las líneas paralelas de la igualdad) que lo tienen como blanco. Si los géneros diferenciados colaboran en aquello que humaniza a los individuos dentro de la cultura actual y se sanciona a quienes no representan bien su género, la experimentación con actos de género (que no sería sino una actuación reiterada) lleva a la desdiferenciación que se manifiesta en la consigna "no queremos ser más esta humanidad". El cuerpo que asume su performatividad, al prepararse y montarse, no solo rompe con la ficción reguladora de la coherencia heterosexual, sino que inventa un estilo, un estilo corporal que ensaya salirse de la humanidad. No casualmente el congreso de Escena Política terminó con una fiesta en la plaza del Congreso: la manifestación de una humanidad que no desea ser representada, porque ello implicaría ser sometida a las exigencias de una identidad común que permitiría una universalidad políticamente representable.

Actualmente, el arte sin proyecto político emancipatorio en el horizonte, se ha vuelto «democrático». Sus principios artísticos, fundados en una estética de la igualdad, son los principios de la democracia: fraternidad (competencia velada), publicidad (autopromoción constante) y división de poderes. La exigencia de que el arte debe ser participativo, se sostiene en la creencia de que la discusión y la generación de nuevos pactos y consensos crean algo, cuando esto sólo es posible si hay un acuerdo previo que, en general, está regulado por una relación de sometimiento y desigualdad concreta entre artistas e instituciones. De modo que, siendo el activismo una categoría más de la industria cultural y el arte político una demanda de los museos que satisfacen los artistas atrapados en la ideología del "arte contemporáneo", en la actualidad, no es fácil distinguir el arte reconciliado que presenta conflictos estetizados (y en muchos 
casos sirve como noticiero para informar al público del turismo internacional de los problemas locales), de aquel arte que es conflicto concreto, discontinuidad entre lo visible y enunciable de una época y capaz de transformación.

Como hemos visto, es posible ubicar en acciones del activismo artístico las funciones del cartel en Brecht pero desplazadas: extrañamiento en lo queer como derecho a lo diferente (la ruptura de la identificación como la diferencia entre sexo y género), el montaje pero de sí mismos entendiendo a los cuerpos no como superficie de proyección sino como configuración y práctica significante dentro de un campo cultural en el que hay jerarquía de géneros y heterosexualidad obligatoria, la emergencia del medio como creación de un espacio de aparición (donde el cuerpo ahora es la situación), y la didáctica en la forma estética del congreso y la manifestación donde el yo se forma no la interioridad sino en la lucha colectiva de la cultura como conflicto.

\section{Por una crítica en cartel}

Lo que se sigue de este tipo de análisis es la hipótesis de que las intervenciones del teatro actual que reclaman ser pensadas están por fuera de las salas de teatro. De modo que quien desee aprehender la escena contemporánea debe primero preguntarse dónde está, pues como hemos visto, sus acciones más arriesgadas están sucediendo fuera de las salas. Entonces, uno de los primeros desafíos de la crítica teatral es precisar y localizar al teatro desenlazado y en tensión con los espacios que lo alojaban, realizándose en nuevas formas, por ejemplo, la forma estética del congreso. Una segunda dificultad es que las herramientas y saberes de la crítica no son algo externo e impropio de los artistas, sino que son ejercidos por ellos mismos en la fundamentación, presentación y ejercicio de sus prácticas. La crítica no es solo un momento inmanente de toda obra, sino un discurso más que los artistas utilizan artísticamente. $Y$, en ese sentido, esta escena invita y solicita a los críticos a participar desde dentro en su dinámica de producción. Exige al teórico la performatividad del saber, es decir, su capacidad de acción. En ese sentido, el activismo cultural habría reemplazado a la crítica cultural, en tanto el activismo sería el modo actual de inscripción de todo aquello que pretende intervenir en la cultura.

En el teatro, al igual que en el cine, se afirma que una obra "está en cartel" cuando está en funciones. Estar en cartel es casi una afirmación ontológica, la obra está presente, es; o, mejor dicho, la obra se está representando. Este trabajo en su formulación del cartel como dispositivo estético político y objeto privilegiado del activismo artístico, intenta también "estar en cartel". Pero no en el modo de la representación, sino en el sentido de poder funcionar como corte e intervención en la madeja de los problemas artísticos actuales. Una intervención que no es inmediata ni espontánea, sino que pretende seguir el ritmo discontinuo del cartel en sus distintas configuraciones históricas, para poder pisar y a su vez intervenir en el trazado de líneas de fuerza vigentes. En una de las vigas de su estudio de trabajo, se ve en las fotos, Brecht había escrito "la verdad es concreta". 


\section{Q Bibliografía}

" Adorno, Th. W. (2013). Dialéctica de la ilustración, Obra completa, Madrid: Akal.

" Adorno, Th. W. (2008). Crítica de la cultura y sociedad I, Obra completa, Madrid: Akal.

»Adorno, Th. W. (2009). Crítica de la cultura y sociedad II, Obra completa, Madrid: Akal.

»Agamben, G. (2018). ¿Qué es un dispositivo?, Buenos Aires: Adriana Hidalgo editora.

»Benjamin, W. (2013). Obra de los pasajes [vol. 1], Madrid: Abada Editores.

»Benjamin, W. (1989). Tentativas sobre Brecht (Iluminaciones III), Buenos Aires: Aguilar.

"Brecht, B. (2009). Teatro completo, Madrid: Alianza editorial.

»Brecht, B. (1970). Escritos sobre teatro (tomo 1), Buenos Aires: Ediciones Nueva Visión.

»Brecht, B. (1972). La política en el teatro, Buenos Aires: Editorial Alfa Argentina.

"Brecht, B. (2004). ABC de la guerra, Madrid: Ediciones del Caracol.

» Butler, J. (2017). Cuerpos aliados y lucha política. Hacia una teoría performativa de la asamblea, Buenos Aires: Paidós.

»Déotte, J. L. (2013). La época de los aparatos, Buenos Aires: Adriana Hidalgo editora.

»Déotte, J. L. (2012). ¿Qué es un aparato estético? Benjamin, Lyotard, Rancière, Santiago de Chile: Ediciones Metales Pesados.

»Deleuze, G. (2007). Dos regímenes de locos. Textos y entrevistas (1975-1995), Valencia: Pre-Textos.

"Didi-Huberman, G. (2013). Cuando las imágenes toman posición, Madrid: Antonio Machado Libros.

"Ewen, F. (2008), Bertolt Brecht. Su vida, su obra, su época, Buenos Aires: Adriana Hidalgo editora.

»Foucault, M. (2018). La arqueología del saber, Buenos Aires: Siglo Veintiuno Editores.

» Foucault, M. (2017). Esto no es una pipa, Buenos Aires: Eterna Cadencia Editora.

»Groys, B. (2016). Arte en flujo, Buenos Aires: Caja Negra editora.

» Habermas J. (1994). Historia y crítica de la opinión pública, Barcelona: Editorial Gustavo Gili.

» Hegel, G. W. F. (2015). Filosofía del arte o Estética, Madrid: Abada Editores.

"Hausmann, R. (2006). Dada en Berlin, Sevilla: Editores Doble J.

»Jameson, F. (2013). Brecht y el método, Buenos Aires: Ediciones Manantial.

» Koselleck, R. (2012). Historias de conceptos, Madrid: Editorial Trotta.

" Marcuse, H. (1970). Cultura y sociedad, Buenos Aires: Editorial Sur. 
» Marx, C. (2011). El decimoctavo brumario de Luis Bonaparte, Buenos Aires: Nuestra América Editorial.

"Schmitt, C. (2005). Romanticismo político, Buenos Aires: Universidad Nacional de Quilmes. 